\title{
New Perspective: Measuring Auditor Professionalism in Fraud Detection
}

\author{
Heni, Yosefa Sayekti, Siti Maria Wardayati \\ Magister of Accounting, Universitas Jember \\ Email: heni@stiewidyagamalumajang.ac.id
}

\section{A R T I C LE IN F O}

Date of entry:

12 July 2020

Revision Date:

27 August 2020

Date Received:

20 September 2020

\begin{abstract}
A B S T R A C T
This research provides a new point of view to measure the professionalism of BPKP auditors in the field of investigation by utilizing the professionalism stated in the Regulation of the Head of BPKP 2010. The research was conducted on BPKP auditors in Java and Bali by filling out a questionnaire distributed via google form. From the distributed questionnaire obtained 51 respondents who participated in this study. Based on the data obtained, hypothesis testing was carried out using the Structural Equation Model (SEM) with the SmartPLS version 3.2.6 software. The results prove that auditor professionalism has a positive and significant effect on fraud detection as evidenced by the t-statistic of 7.526. In other words, the higher the professionalism of the investigative BPKP auditors, the higher their ability to detect fraud. The results also prove that professionalism according to the Regulation of the Head of the BPKP Year 2010 has been carried out properly by the BPKP auditors in the field of investigation and has truly become a work culture that must be carried out.
\end{abstract}

Keywords: Auditor Professionalism, Fraud, Fraud Detection

Cite this as: Heni, Sayekti, Y., Wardayati, S. M. (2020). New Perspective: Measuring Auditor Professionalism in Fraud Detection. Wiga : Jurnal Penelitian Ilmu Ekonomi, 10(2), 191-199. https://doi.org/10.30741/wiga.v10i2.623

\section{INTRODUCTION}

Fraud has been declared an international crisis (Kummer et al., 2015). Fraud cases have hit various sectors both in Indonesia and abroad. Many of the public have been shocked by the incidence of fraud, such as the case that happened to the Thosiba company as the 10th largest company in Japan in May 2015, surprisingly saying that Thosiba was investigating an internal accounting scandal, namely lies in accounting fraud worth 1.22 billion US dollars. This lie was exposed when a third party conducted an internal investigative audit of Thosiba's company finances (https://integrityindonesia.com). In addition, there is also the Satyam fraud scandal (Bhasin, 2013) which has also caught the attention of developed countries. Of the many cases of fraud that have occurred, it is evident that fraud is not indiscriminate (Suganda et al., 2018), and no company is immune to the power of fraud (Bhasin, 2013). 
Fraud occurs due to behavioral factors (Ramamoorti, 2008), such as financial and non-financial pressures to produce better performance and exceed expectations (Dewayani \& Chariri, 2015; Albrecht et al., 2004), and challenges to fight the system (Albrecht et al. al., 2009) is a trigger for fraud. Act of fraud does not actually provide any benefit, the perpetrator can only enjoy a higher lifestyle or temporarily guard against company failure (Albrecht et al., 2009), but the long-term costs incurred in connection with investigations, arrests, trust, trials, loss of business and other consequences cannot be measured by quantity (Albrecht et al., 2009; Levi \& Burrows, 2008).

Fraud is a deliberate act to obtain money, property or other benefits that are not legally owned (Mangala \& Kumari, 2015), through improper or illegal means at the expense of a public entity (Munteanu et al., 2017), which is driven by the existence of pressures, opportunities or opportunities, and rationalization (Abdullahi \& Mansor, 2018; Latan et al., 2018), which arise when inadequate internal controls or the ability to obscure fraud are behind transactions (Albrecht et al., 2010).

Fraud is a very extraordinary crime, which is caused by the involvement of individuals who try to falsify, mislead, hide and manipulate data which will cause serious problems and sacrifice other parties (Abdullahi \& Mansor, 2018), so that extraordinary handling is needed. also. It takes an accountant who is professional in carrying out an audit in order to be able to detect fraud, because professionalism is the main requirement in carrying out an audit (Agusti \& Pertiwi, 2013; Gashi, 2016). High professionalism will encourage the freedom of auditors to have an opinion so that they are more secure and free from pressure from any party (Agusti \& Pertiwi, 2013). Gashi (2016) states that professionalism has a stronger influence than other prerequisites, professionalism is also directly related to auditor quality and auditor performance (Arumsari \& Budiartha, 2016). Windasari \& Juliarsa (2016) stated that professionalism will make auditors work indiscriminately, anyone who commits fraud will not hesitate to disclose. This is due to the principle of auditor professionalism which encourages disclosure of fraud to related parties. Auditor professionalism is very important to carry out an audit, because it can improve audit quality (Dewi \& Murti, 2019), and does not cause conflict between auditors and management (Heyrani et al., 2016) so that the audit assessment is more independent.

Professionalism must be used as the main requirement that must be carried out by auditors to carry out an audit (Matarneh et al., 2015), because auditor professionalism affects the disclosure of fraud (Atmaja, 2016; Sastiana \& Sumarlin, 2016). Good professionalism will be able to restore the identity of public servants carried out by accounting professionals for a decrease in the professional aspirations of accountants which cause erosion of public trust (Lail et al., 2017), and with professionalism auditors feel they can make the greatest impact (Lampe \& Garcia , 2003).

The magnitude of the benefits of professionalism that must be carried out by auditors for the audit process encourages researchers to conduct research related to auditor professionalism in fraud detection. With a new perspective using the concept of the Head of BPKP Regulation (2010) which includes; understanding of the science of supervision by auditors, competence and experience, work attitude with integrity, creative orientation that leads to added value for the achievement of organizational goals, and increased understanding of audit technology. The reason the researcher uses the concept of the BPKP Head Regulation (2010) is because this study measures the professionalism of auditors in BPKP auditors in Java and Bali and is expected to measure the professionalism of auditors in accordance with the Regulation of the Head of BPKP (2010) because professionalism is a BPKP work culture that must be implemented.

Attribution theory introduced by Fritz Heider in 1958, is a theory that studies the process of how a person describes an event, reason, or cause for the behavior of others and even our own behavior is influenced by internal factors such as traits, characters, attitudes, etc. affect the behavior of a person or individual (DP et al., 2014; Yudha et al., 2017). Attribution theory supports this research, described through the professionalism of auditors because with professionalism, auditors can improve audit quality (Dewi \& Murti, 2019). Because professionalism is a characteristic 
possessed by auditors as a trigger for auditing activities in determining audit quality (Sukesi, 2015).

Professionalism is an element of motivation that exists in a person to have a high performance in duty (Sastiana \& Sumarlin, 2016), and is a must so that the profession can survive in the future (Martak, 2015). The right indicator to describe the professionalism of auditors using the concept put forward by Hall (1968) is through professional community affiliation (affiliation with fellow professions); Social obligation (social obligation); Belief in self-regulation (belief in the rules of the profession); Professional dedication (professional dedication); and Autonomy demands (independence) as well as indicators contained in the BPKP Head Regulation (2010), which consists of; understanding of the science of supervision by auditors, competence and experience, work attitude with integrity, creative orientation that leads to added value for the achievement of organizational goals, and increased understanding of audit technology. The choice of measurement includes auditor professionalism according to the Regulation of the Head of BPKP (2010) because the respondents in this study were BPKP auditors in the field of investigation and would be better measured by using the regulations applied to their organization, because they would describe the professionalism of the auditors.

Fraud detection according to Kumaat (2011: 156) is an effort to obtain sufficient indications of cheating, as well as narrowing the space for the perpetrators of fraud, which means that when the perpetrator realizes that his practice has been known, it is too late to dodge. Kumaat (2011: 156) states that detecting fraud is measured by skill and knowledge, having high alertness, having accuracy and accuracy. Fraud detection is measured through indicators of having skills and knowledge, having accuracy and accuracy stated by (Kumaat, 2011: 156).

The rise of fraud cases that occur must be supported by the professionalism of the auditors. Because the professionalism of auditors is the main requirement in carrying out an audit (Agusti \& Pertiwi, 2013; Gashi, 2016) and professionalism is the main key for the successful implementation of BPKP's duties (Regulation of the Head of BPKP, 2010). The professionalism of auditors to support fraud detection was expressed by Atmaja (2016); Ira \& Nofryanti (2016); Sastiana \& Sumarlin (2016), and professionalism can have the greatest impact (Lail et al., 2017; Lampe \& Garcia, 2003). Because the principle of professionalism inherent in auditors will encourage disclosure of fraud to related parties and encourage the auditor's freedom of opinion (Agusti \& Pertiwi, 2013).

\section{METHOD}

The population of this study includes investigative auditors who work at the Financial and Development Supervisory Agency (BPKP) in Java and Bali, using the purposive sampling method as a sampling technique. In this technique, the determination of the sample is taken based on the criteria from Mulyadi (2014: 58) which have been determined in order to represent the population. The criteria used in sampling are that auditors must have at least a diploma education, have a special certificate or training, work experience of at least 1 (one) year, and have a minimum position as the first auditor.

In this study, primary data collection was carried out by distributing questionnaires in the form of questions designed using a linkert scale, filled in by respondents who worked at BPKP in Java and Bali. Data collection techniques in this study used a questionnaire conducted to auditors in the field of investigation of BPKP representatives in Java and Bali to answer questions posed through a questionnaire via google form by selecting the appropriate answer, then continued with interviews with representatives of functional auditors to complete the results. from the analysis that has been done. Then carried out a descriptive analysis of the responses given by respondents to the questionnaire by describing or describing the data that had been collected. All variables in 
this study were measured using a 5-point Likert scale and statistical analysis was carried out using the SmartPLS Structural Equation Model (SEM) version 3.2.6.

\section{RESULTS AND DISCUSSION}

The variable descriptions of the 51 respondents who participated in the study can be seen in the following table:

Table 1. Characteristics of Respondents

\begin{tabular}{|c|c|c|c|c|}
\hline No. & Characteristics & Category & Total & Procentage \\
\hline \multirow[b]{2}{*}{1.} & \multirow{2}{*}{ Gender } & Men & 48 & $94,1 \%$ \\
\hline & & Women & 3 & $5,9 \%$ \\
\hline \multirow{2}{*}{2.} & \multirow{2}{*}{ Status } & Married & 47 & $92,2 \%$ \\
\hline & & Single & 4 & $7,8 \%$ \\
\hline \multirow{4}{*}{3.} & \multirow{4}{*}{ Jabatan } & Auditor Pertama & 13 & $25,5 \%$ \\
\hline & & Auditor Muda & 11 & $21,6 \%$ \\
\hline & & Auditor Madya & 20 & $39,2 \%$ \\
\hline & & Pejabat Struktural & 7 & $13,7 \%$ \\
\hline \multirow{3}{*}{5.} & \multirow{3}{*}{ Education } & S1 & 35 & $68,6 \%$ \\
\hline & & $\mathrm{S} 2$ & 15 & $29,4 \%$ \\
\hline & & S3 & 1 & $2 \%$ \\
\hline \multirow{4}{*}{6.} & \multirow{4}{*}{ Working area } & Central BPKP & 19 & $37,3 \%$ \\
\hline & & BPKP of Central Java Province & 3 & $5,9 \%$ \\
\hline & & BPKP of East Java Province & 20 & $39,2 \%$ \\
\hline & & BPKP of the Province of Bali & 9 & $17,6 \%$ \\
\hline
\end{tabular}

Source: Primary data processed (2020)

Based on Table 1 above, it is known that the respondents who answered the questionnaire consisted of 48 men and 3 women with married status as many as 47 auditors and 4 auditors who were not married. The highest positions are pejabat struktural with 7 auditors, 20 auditor madya, 13 auditor pertama, and 11 auditor muda, with the highest education are 1 auditor S3, 35 auditors with S1 education, and 15 auditors with S2 education. The BPKP of East Java Province filled the most auditor work areas with 20 respondents who responded to the auditors, 19 respondents from Central BPKP, 9 respondents from BPKP Province of Bali, and 3 respondents from BPKP Central Java Province.

Table 2. Percentage and Average of Respondents' Answers

\begin{tabular}{clccc}
\hline No. & & Indicator & Average & Procentage \\
\hline 1. & Auditor Professsionalism & 4,61 & 92,2 \\
2. & Fraud Detection & 4,16 & 83,2 \\
\hline
\end{tabular}

Source: Primary data processed (2020)

Based on the questions about each indicator presented in Table 2 above, it can be seen that the answers to the auditors answering statements on professionalism get an average of 4.61 (strongly agree), this means that $92.2 \%$ of the auditor's professionalism has been carried out well by the investigative BPKP auditors. And in detecting fraud, $83.2 \%$ of auditors have expertise, knowledge, are accurate, careful and capable of detecting fraud.

In this study, the validity test was conducted on 51 respondents who participated in this study, namely the BPKP auditors in the field of investigation. In evaluating the Moodel measurement, the vaidity and reliability tests were carried out. In the validity test, two stages were carried out, namely the convergent validity test and the discriminant validity test (Ghozali, 2014: 39). 
Convergent validity testing is carried out in two ways, namely by looking at the loading factor and seeing the Average Variance Extracted (AVE) value. As stated by Ghozali (2014: 41) that the consideration of validity criteria is based on the loading factor value in the construct measurement, if it shows above 0.7 then it is declared the most ideal and a value above 0.5 indicates that the validity is acceptable.

Table 3. Convergent Validity Test via Average Variance Extracted (AVE)

\begin{tabular}{lccc}
\hline Variable & $\begin{array}{c}\text { Cronbach's } \\
\text { Alpha }\end{array}$ & $\begin{array}{c}\text { Composite } \\
\text { Reliability }\end{array}$ & $\begin{array}{c}\text { Average } \\
\text { Variance } \\
\text { Extracted (AVE) }\end{array}$ \\
\hline Auditor Professionalism & 0,903 & 0,914 & 0,521 \\
Fraud Detection & 0,954 & 0,964 & 0,844 \\
\hline
\end{tabular}

Source: Data processed (2020)

Based on the table above shows that the AVE value is above 0.5 so that the convergent validity can be accepted. In examiners using the loading factor, it is also above the value of 0.05 . From the two tests through the loading factor and AVE, it is said that all statements on the research instrument have met the validity criteria.

After testing the convergent validity, the discriminant validity test was carried out by comparing the AVE of each construct with the correlation between the construct and other constructs in the model (Ghozali, 2014: 40). From the discriminant validity test, the results are presented in table 4:11 below:

Table 4. Discriminant Validity Test Results through Comparison of AVE with Constructs

\begin{tabular}{lcc}
\hline & Professionalism & Fraud Detection \\
\hline Auditor Professionalism & 0,721 & \\
\hline Fraud Detection & 0,520 & 0,919 \\
\hline
\end{tabular}

Source: Data processed (2020)

Based on the discriminant validity test in table 4.11, through the AVE comparison, it can be seen that the AVE value (which is gray) of each construct (which is white) has a value greater than 0.05 . So based on the discriminant validity test using the AVE value, it is said that the discriminant validity test has been fulfilled. This is in accordance with what was stated by Ghozali (2014: 65) that discriminant validity is said to be good, if it is greater than 0.50 .

Reliability test is used to measure the consistency of an instrument sequentially. In this study, using two reliability tests presented by Ghozali (2014: 65), namely Cronbach's Alpha and composite reliability. Based on table 3, it is known that Cronbach's Alpha and Composite Reliability are above 0.7 . This shows that the consistency between constructs is in accordance with that expressed by Ghozali (2014: 65) which is above 0.7 .

Table 5. R-Square Value

\begin{tabular}{lcc}
\hline & Variable & R-Square \\
\hline Fraud Detection & 0,520 \\
\hline
\end{tabular}

Source: Data processed (2020)

Based on the table above, it shows that the R-Square value for the fraud detection variable is 0.520. This means that the percentage of the magnitude of the influence of auditor professionalism (X) on fraud detection (Y) gives a value of 0.520 . It can be interpreted that the dependent latent variable can be explained by the independent latent variable by $52.0 \%$ and the remaining $48.0 \%$ is influenced by other variables outside of this study. 
$\mathrm{Q}^{2}$ testing is used for predictive relevancy in the constructive model, through the value of $\mathrm{Q}^{2}$ it can be seen the goodness of fit assessment. In the Q-square, it can be seen how well the observation value generated by the model and also its parameter estimates, if the Q-square value $>0$ (zero) is said to be predictive relevance value, but Q-square < than 0 (zero) indicates that it is less predictive. relevance (Ghozali, 2014: 41). The calculation of $\mathbf{Q}^{2}$ is as follows (Ghozali \& Latan, 2012): $\mathrm{Q}^{2}=1-\left(1-\mathrm{R} 1^{2}\right), \mathrm{Q}^{2}=1-(1-0,520), \mathrm{Q}^{2}=1-(0,48), \mathrm{Q}^{2}=0,520$.

The result of the calculation shows that the $\mathrm{Q}^{2}$ value is 0.520 . Based on these results, it shows that the value of $\mathrm{Q}^{2}$ is greater than 0 (zero), so it can be said that the model has predictive relevance for endogenous variables, this is in accordance with the opinion of Ghozali (2014: 41).

Table 6 Evaluation of Goodness of Fit

\begin{tabular}{lcc}
\hline \multicolumn{1}{c}{ Konstruk } & R Square & Communality \\
\hline Auditor Professionalism & & 0,521 \\
Fraud Detection & 0,520 & \\
Average & 0.520 & 0.521 \\
\hline
\end{tabular}

Source: Data processed (2020)

Based on the results in Table 4:14 above, the GoF calculation can be done as follows: Gof $=\sqrt{\overline{\operatorname{Com}} \times \overline{R^{2}}}=\sqrt{0,521 \times 0,520}=0,271$. From these calculations, it can be concluded that the structural model in this study generally has moderate predictive properties (medium GoF), which means that the model has a medium ability to explain empirical data, especially in explaining the influence model of auditor professionalism on fraud detection.

Table 7. Direct Effect Test

\begin{tabular}{llll}
\hline The relationship between constructs & $\begin{array}{l}\text { Path } \\
\text { coefficient }\end{array}$ & t-statistic & p-value \\
\hline Auditor Professionalism $\rightarrow$ Fraud Detection & 0,520 & 7,526 & 0,000 \\
\hline
\end{tabular}

Source: Data processed (2020)

The results of the direct effect hypothesis test in table 7 show that the effect of the professionalism of the auditors in fraud detection was found to be significant in the BPKP auditors with a path coefficient of 0.501 with a t-statistic value (t-count) of 4.054, so that it can be concluded that the tcount is greater. from the t-table (4.054>1.96). Based on these findings, hypothesis 2 in this study is accepted, meaning that there is a very large and positive influence on the professionalism of auditors in fraud detection on BPKP auditors.

The results of the research findings indicate that the professionalism of auditors is a predictor variable that is more able to reflect the disclosure of fraud in the investigative BPKP auditors. The effect of auditor professionalism in this study is said to be perfect, because it has a t-tatistic value of 0,000 so that this hypothesis is accepted. According to BPKP, professionalism is a work culture that must be upheld, because professionalism is the main key and basis for developing BPKP's image. Professionalism in BPKP auditors must be carried out in accordance with the Regulation of the Head of BPKP 2010.

This research also supports the theory of attribution with auditor behavior which lies in the characteristics of the auditor, where these characteristics will be able to spur the auditors to be active in determining audit quality (Sukesi, 2015) which is illustrated by the professionalism of the auditors. Professionalism can improve audit quality (Agusti \& Pertiwi, 2013). With professionalism, auditors are able to formulate their opinions appropriately without partiality for anyone. 
The findings of this study confirm several previous studies conducted by Agusti and Pertiwi (2013); Gashi (2016); Matarneh et al (2015) who revealed that professionalism is the main requirement in carrying out an audit, and Atmaja (2016); Sastiana and Sumarlin (2016) prove that the professionalism of auditors affects the disclosure of fraud, and Vinciguerra (2001) who states that the presence of professionalism will minimize pressure on auditors in making judgments, so that auditors become more independent, this is evidenced by the t-statistic value of 0,000 . These results indicate that the professionalism of the auditors really has a big influence on the detection of fraud in the investigative BPKP auditors.

Based on the questionnaire distributed via google form, it can also be seen that in handling cases of fraud, especially corruption, a heavier sentence (or more maximum punishment) is required so that the perpetrator of fraud does not repeat it again. It takes an increase in the company's internal control system, it requires commitment and support from the community and management to eradicate corruption, so that fraud can be minimized and eradicated.

\section{CONCLUSION}

This study aims to test the professionalism of BPKP auditors in the field of investigation by using measurements in the Regulation of the Head of BPKP 2010. In this case, the measurement of auditor professionalism based on the Regulation of the Head of BPKP 2010 has never been carried out by previous research, and researchers suggest that the use of indicators is in accordance with the Regulation of the Head of BPKP 2010. so that it is preferred and used to measure the professionalism of the BPKP auditors because this professionalism is the work culture of the BPKP, so that the results of the analysis are more direct. Based on the results of the analysis, it shows that the professionalism of auditors shows a positive and significant effect on fraud detection, the better the professionalism of an auditor, the better the detection of fraud.

With an attitude of professionalism that is highly respected by the BPKP auditors in the field of investigation, through the many audits that have been carried out, it can be seen that other causes that make someone dare to commit fraud are due to pressure, internal control systems and weak systems. Some of these causes were identified by researchers based on a questionnaire filled out by the BPKP auditors in the field of investigation. The causes written by the respondent are proven that these causes trigger someone to commit fraud which is proven and supported by existing studies, such as research conducted by Albrecht et al. (2004); Dewayani \& Chariri, (2015) show that there is pressure from superiors, work environment, management, and pressure to fulfill a lifestyle, and research by Albrecht et al. (2009) proved that a weak internal control system is the cause for someone to commit fraud. Many things trigger a weak system for committing fraud, one of which is because someone wants to try to find out how good the system is at the company and the challenges to fighting the system, as well as a lack of a culture of shame in a person.

\section{REFERENCE}

Abdullahi, R., \& Mansor, N. (2018). Fraud Prevention Initiatives in The Nigerian Public Sector. Journal of Financial Crime, 25(2), 527-544. https://doi.org/10.1108/JFC-02-2015-0008

Agusti, R., \& Pertiwi, N. P. (2013). Pengaruh Kompetensi, Independensi dan Profesionalisme terhadap Kualitas Audit (Studi Empiris pada Kantor Akuntan Publik Se Sumatera). Jurnal Ekonomi, 21(3 September), 1-13.

Albrecht, C., Turnbull, C., Zhang, Y., \& Skousen, C. J. (2010). The relationship between South Korean chaebols and fraud. Management Research Review, 33(3), 257-268. https://doi.org/10.1108/01409171011030408

Albrecht, W. S., Albrecht, C. C., \& Albrecht, C. O. (2004). Fraud and Corporate Executives: Agency, Stewardship and Broken Trust. Journal Of Forensic Accounting, V, 109-130. 
Albrecht, W. S., Albrecht, C. C., Albrecht, C. O., \& Zimbelman, M. (2009). Fraud Examination (3rd Editio). Canada: Nelson Education, Ltd.

Arumsari, A. L., \& Budiartha, I. K. (2016). Pengaruh Profesionalisme Auditor, Independensi Auditor, Etika Profesi, Budaya Organisasi, dan Gaya Kepemimpinan Terhadap Kinerja Auditor pada Kantor Akuntan Publik di Bali. E-Jurnal Ekonomi Dan Bisnis Universitas Udayana, 5(8), 2297-2304.

Atmaja, D. (2016). Pengaruh Kompetensi, Profesionalisme, dan Pengalaman Audit terhadap Kemampuan Auditor Badan Pemeriksa Keuangan (BPK) dalam Mendeteksi Fraud dengan Teknik Audit Berbantuan Komputer (TABK) sebagai Variabel Moderasi. Media Riset Akuntansi, Auditing \& Informasi, 16(1), 53-68.

Bhasin, M. (2013). Corporate Accounting Scandal At Satyam: A Case Study Of India's Enron. European Journal of Business and Social Sciences, 1(12), 25-47.

BPKP. (2010). Peraturan Kepala Badan Pengawasan Keuangan dan Pembangunan.

Dewayani, R. A., \& Chariri, A. (2015). Money Laundering dan Keterlibatan Wanita (Artis): Tantangan Baru Bagi Auditor Investigatif. Diponegoro Journal of Accounting, 4(3), 1-6.

Dewi, P. P., \& Murti, A. . T. A. (2019). Faktor-Faktor yang Mempengaruhi Kualitas Audit. Media Bina Ilmiah, 13(7), 1361-1368.

DP, E. N., Julita, \& Wahyudi, D. P. (2014). Pengaruh Etika, Kompetensi, Pengalaman Auditor dan Situasi Audit terhadap Ketepatan Pemberian Opini Audit Melalui Pertimbangan Materialitas dan Skeptisisme Profesional Auditor. Jurnal Ilmiah STIE MDP, 3(2), 116-132.

Gashi, M. (2016). Preconditions That Affect in Increasing Control Effect and Increased Chance for tax Fraud Detection. International OFEL Conference on Governance. Management and Entrepreneurship, 436-443.

Ghozali, I. (2014). Struktural Equation Model: Metode Alternatif dengan Partial Least Squares (PLS) (Edisi 4). Semarang: Universitas Diponegoro Semarang.

Ghozali, I., \& Latan, H. (2012). Partial Least Square: Konsep, Teknik dan Aplikasi SmartPLS 2.0 M3. Semarang: Badan Penerbit Universitas Diponegoro.

Hall, R. H. (1968). Professionalization and Bureaucratization. American Sociological Review, 33(1), 92-104.

Heyrani, F., Banimahd, B., \& Roudposhti, F. R. (2016). Investigation of the Effect of Auditors ' Professionalism Levels on Their Judgment to Resolve the Conflict between Auditor and Management. Procedia Economics and Finance, 36, 177-188. https://doi.org/10.1016/S2212-5671(16)30029-6

Ira, N., \& Nofryanti. (2016). Pengaruh Profesionalisme dan PengalamanAuditor terhadap Kemampuan Auditor dalam Mendeteksi Kecurangan. Jurnal Ilmiah Akuntansi, 4(2), 958980.

Kumaat, V. G. (2011). Internal Audit. Jakarta: Erlangga.

Kummer, T., Singh, K., \& Best, P. (2015). The Effectiveness of Fraud Detection Instruments In Not-For-Profit Organizations. Managerial Auditing Journal, 30(4/5), 435-455. https://doi.org/10.1108/MAJ-08-2014-1083

Lail, B., Macgregor, J., Marcum, J., \& Stuebs, M. (2017). Virtuous Professionalism in Accountants to Avoid Fraud and to Restore Financial Reporting. Journal of Business Ethics, 140(4), 687-704. https://doi.org/10.1007/s10551-015-2875-y

Lampe, J. C., \& Garcia, A. (2003). Professionalism in Internal Auditing. Internal Auditing, 18(6), 11.

Latan, H., Jabbour, C. J. C., \& Jabbour, A. B. L. de S. (2018). “ Whistleblowing Triangle ”: Framework and Empirical Evidence. Journal of Business Ethics. https://doi.org/10.1007/s10551-018-3862-x

Levi, M., \& Burrows, J. (2008). Measuring The Impact Of Fraud In The UK A Conceptual and Empirical Journey. British Journal Of Criminology, 48(3), 293-318. https://doi.org/10.1093/bjc/azn001

Mangala, D., \& Kumari, P. (2015). Corporate Fraud Prevention and Detection: Revisiting The Literature. Journal of Commerce \& Accounting Research, 4(1), 52-62. 
Martak, M. N. M. (2015). Analisis Pengaruh Profesionalisme dan Komitmen Organisasi terhadap Prestasi Kerja Melalui Kepuasan Kerja pada Auditor Kantor Akuntan Publik di Surabaya. Jurnal Ekonomi Dan Bisnis, XXV(1), 54-68.

Matarneh, A. J., Moneim, U. A., \& Al-nimer, M. (2015). The Intellectual Convergence between the Forensic Audit and the External Auditor toward the Professionalism in Jordan. International Journal of Business and Management, 10(11), 138-148. https://doi.org/10.5539/ijbm.v10n11p138

Mulyadi. 2014. Auditing. Edisi Keenam. Bandung: Salemba Empat

Munteanu, V., Copcinschi, L., Luschi, C., \& Laceanu. (2017). Internal Audit - Determinant Factor In Preventing And Detecting Fraud Related Activity To Public Entities Financial Accounting. Knowledge Horizons - Economics, 9(1), 55-63.

Ramamoorti, S. (2008). The Psychology and Sociology of Fraud: Integrating the Behavioral ... Issues in Accounting Education, 23(4), 521-533.

Sastiana, \& Sumarlin. (2016). Pengaruh Audit Forensik Dan Profesionalisme Auditor Terhadap Pencegahan Fraud Dengan Kecerdasan Spiritual Sebagai Variabel Moderating Pada Perwakilan BPKP Provinsi Sulawesi Selatan. Akuntansi Peradaban, I(1), 106-127.

Suganda, T. R., Ambarwati, S., \& Astuti, T. (2018). Pengaruh Skeptisisme Profesional, Independensi, Dan Pengalaman Auditor Terhadap Kemampuan Auditor Mendeteksi Fraud. Jurnal Liquidity, 7(1), 19-25.

Sukesi, S. (2015). Pengaruh Karakteristik Personal Auditor Terhadap Penerimaan Perilaku Disfungsi Audit pada Unit Organisasi TNI Angkatan Laut. Media Riset Akuntansi, Auditing \& Informasi Vol., 15(2), 161-170.

Vinciguerra, B. M. (2001). Auditor Independence: An Examination of the Effect of Self-Interest Threats and Organizational Safeguards on Auditor Judgment. Drexel University. Proquest Dissertations Publishing.

Windasari, M. Y., \& Juliarsa, G. (2016). Pengaruh Kompetensi, Independensi, dan Profesionalisme Auditor Internal dalam Mencegah Kecurangan pada BPR di Kabupaten Badung. E-Jurnal Akuntansi Universitas Udayana, 17(3), 1924-1952.

Yudha, P. A., Sujana, E., \& Purnamawati, G. A. (2017). Pengaruh Kompleksitas Audit, Due Professional Care, Tekanan Anggaran Waktu, dan Pengalaman Auditor terhadap Kualitas Audit dengan Variabel Moderasi Pemahaman terhadap Sistem Informasi (Studi Empiris pada Auditor KAP di Bali). E-Journal S1 Ak Universitas Pendidikan Ganesha, 8(2).

https://www.integrity-indonesia.com/id/blog/2017/09/14/skandal-keuangan-perusahaan-toshiba/ (Accessed on 5 June 2019) 